\author{
Asian Journal of \\ Medical and Biological Research \\ ISSN 2411-4472 (Print) 2412-5571 (Online) \\ www.ebupress.com/journal/ajmbr
}

\title{
Article
}

\section{Fishing gears and crafts used in Gumti river of Muradnagar upazila, Bangladesh}

\author{
Md. Nazmus Sakib, Md. Robiul Hasan* and Md. Akram Ullah \\ Department of Fisheries and Marine Science, Noakhali Science and Technology University, Noakhali-3814, \\ Bangladesh
}

*Corresponding author: Md. Robiul Hasan, Department of Fisheries and Marine Science, Noakhali Science and Technology University, Noakhali-3814, Bangladesh. E-mail: rhasan_rony@yahoo.com

Received: 16 August 2020/Accepted: 20 September 2020/ Published: 30 September 2020

\begin{abstract}
The study describes traditional fishing gears and crafts available at Gumti river of Muradnagar upazila in Cumilla district, Bangladesh. The study was carried out by the collection of primary data through surveying individual fishermen. We found that there are 6 fishing gears available in the study area. Among them, 5 types of the fishing net (i.e., cast nets, seine net, lift net, push net, gill net) and a kind of fishing trap was identified. We also found 4 different types of crafts, including dingi nauka, kosha nauka, chandi nauka, and soto tempu. Synthetic twines are used for net making, which increases the fishing efficiency significantly. The life span of these nets varies according to their building materials. Sun-drying was the best approach for net preservation rather than using any chemicals or medicine. Besides, traditionally mehogany, raintree, shill koroi, garjan, gamari, jarul, chapulis woods and bamboos were found to be boat construction materials. The boats are painted with tar or pitch and burn oil for the protection. No modern instruments such as a compass, life-saving equipment are used by these boats. Most of the boats are mechanized, i.e. operated by engine.
\end{abstract}

Keywords: Muradnagar; gumti river; fishing gear; fishing craft

\section{Introduction}

Bangladesh is popularly called riverine country while many rivers exist on it (Banglapedia, 2012). Bangladesh has diversified water bodies and it has two different forms of water bodies such as open waters (e.g. rivers, streams) and closed waters (e.g. pond, reservoir, lake). Among open water bodies, Gumti river is one of the vital ecosystems which have the potential to increased fish diversity. Gumti river is located at Muradnagar upazila of Cumilla district which supports diverse fisheries communities. Many fishermen families depend directly or indirectly on this river ecosystem (Uddin et al., 2020). There are many fishing gears and crafts currently being operated in the Gumti river for fishery resources exploitation. Fishing activity nowadays reaches in a situation that cannot be possible without fishing nets and crafts.

The development of fishing gear came from early ages when fishermen became concerned about the methods of catching fish. Fishing gear refers to devices which are used for catching fish world-wide. It includes nets, simple hook, traps, lines, alluring fish device and wounding gears (Chakraborty et al., 1995). Among those fishing gears, fishing nets are used globally. Fishing nets are the devices which has variety in shape and size, used for capturing various fish. According to ISO (1974), the net is a meshed structure of various shape and size, composed of one or more system of yarns interlaced or joined. In addition, several other fishing gears may also be available, and their number of availability may vary from one fishing region to another fishing region. For example, Chong (1979) found 21 gears surrounding the areas of Chandpur, Muhuri, Halda, and Ichamati while Bangladesh Centre of Advanced Studies (1989) identified approximately thirty different types of fishing gears in Haiti beel. Besides, DOF (2005) found different fishing gears including jhaki jal, uther jal, veshal/kora jal, dal jal, konaber jal, tona jal, gora jal, sarda jal, current jal, ram jal, kochal jal, katha jal, tonti jal, koi jal, punti jal in the beels and haor of Netrokona and Sunamganj district. Dewan and Mazid (1994) identified a total of 90 fishing gears that are being used for fishing in different types of water bodies of the country. 
Besides fishing gears, fishing craft is the device which is used to bring the collected fishes, such as various mechanized and non-mechanized boats. Fishing crafts provides the facility of preservation, processing and storing. Various kinds of crafts are in available in ocean and other small-scale fishery. Moreover, three main types of traditional boats exist in the country; these are dinghi, chandi and balam (Karim, 1978). Ahmed (1954) first described seven different traditional fishing crafts in Bangladesh which are balam boat, chandi boat, dinghi boat, kosha boat, bachari boat, donga and raft.

Knowledge regarding detail description, way of operation and kinds of fishing gears and craft have the potential for manifesting a river ecosystem management practice through catching fish effectively. Consequently, a number of studies attempted to gain information on various kinds of fishing gears and crafts in several river, lake, floodplain, haor, boar, beel, irrigation projects (DOF, 2005; FAO, 1986; Jhingram, 1963; Karim, 1978; Khaleque and Islam, 1985; Kibria, 1983; Moula, G. et al., 1993; Rahman et al., 1993; Wahiduzzaman and Hasan, 2020). However, such information about fishing gears and crafts in the Gumti river of Muradnagar upazila is still unexplored. Therefore, our current study aimed to gain information on various kinds of fishing gears and crafts in the Gumti river.

\section{Material and Methods}

\subsection{Study area}

The Gumti river and its adjacent floodplain area of Muradnagar upazila $\left(23^{0} 38.3^{\prime} \mathrm{N} 90^{0} 56^{\prime} \mathrm{E}\right)$, Bangladesh was the main study area.

\subsection{Period of the study}

The period of the study was four months (April 2019 to July 2019).

\subsection{Data collection}

The data of fishing gears and crafts were collected in groups based on their mode of operations, structural pattern and building materials, the number of people needs to operate, construction cost, the longevity of the gears and crafts. Primary data were collected in two different ways, e.g. (i) questionnaire interview and (ii) focus group discussion (FGD). Collected data were then validated by a cross-check interview. The questionnaire interview was planned to get responses of fishermen to particular questions. For FGD, we organized three (3) group discussions for each village. Each group consisted of 7-9 fishers, including all aged people (e.g., men, women, young or older people). Collected data were cross-checked by UFO (Upazila Fisheries Officer), and the fishing related personnel.

\section{Results and Discussion}

Our results found that the various types of fishing gears and crafts are being used surrounding the Gumti River by choice of fishers. We estimated that there are 6 fishing gears available in the study area (Table 1). Among them, 5 types of the fishing net (i.e., cast nets, seine net, lift net, push net, gill net) and a kind of fishing trap was identified. We also estimated 4 different types of crafts, including dingi nauka, kosha nauka, chandi nauka, and soto tempu.

Table 1. Fishing gears used at Muradnagar.

\begin{tabular}{lllll}
\hline Category & Name of the gears & Shape & Mesh size (inch) & Construction cost (taka/net) \\
\hline Cast net & Jhaki jal/Khapla jal & Conical & $0.25-0.5$ & $5000-10000$ \\
\hline Seine net & Boro ber jal & Rectangular & 1 & $30000-50000$ \\
& Choto ber jal & Rectangular & $0.5-1$ & $20000-25000$ \\
\hline Lift net & Dharma jal/khara jal & Triangular & $0.1-0.2$ & $10000-12000$ \\
\hline Push net & Thela jal & Triangular & $0.1-0.2$ & $4000-4500$ \\
\hline Gill net & Current jal & Rectangular & $30-50 \mathrm{~mm} \mathrm{\&} \mathrm{10-20mm}$ & $600-900$ \\
\hline Traps & Anta & Cylindrical & N/A & N/A \\
\hline
\end{tabular}

\subsection{Fishing Gears}

\subsubsection{Cast net}

Cast nets composed of three parts, e.g. (i) the upper part - called net band; (ii) the middle part - meshed net; and (iii) the lower part - attached sink). An example of a cast net includes jhaki jal/khapla jal, which is found in the study area. 


\subsubsection{Jhaki jal/khapla jal}

The length of jhaki jal is $10-15 \mathrm{~m}$. A variety of synthetic twines (e.g., monofilaments, polyamide, polypropylene, nylon rope $(F A O, 1986)$ are used for making the net. However, nylon twines are locally popular due to cheaper and easily available. The mesh size is $0.25-0.5$ inch. One sinker per $0.2 \mathrm{~m}$ net is introduced and made by iron and zinc alloy, which are found locally. One person operates one net. The attractive fish device is not mandatory for catching fishes. The making cost of this net is 5000-10000 taka/10-15m net. The net lasts for $1-2$ years. Cast net can be preserved easily by drying the net using sunlight and putting it in a dry place. Chemical and medicine are not used for the preservation of the net. This net is mainly used for catching fishes including Labeo bata, Monopterus cuchia, Anabas testudineus, Pangasius pangasius.

\subsubsection{Seine net}

Seine nets are large rectangular shaped net with upper and lower bamboo lines which are attached to be a point and from one rope. The upper portion of the net is aligning together with afloat. Two types of seine net are available in the study area.

\subsubsection{Boro ber jal}

Boro ber jal has a long wing and rope. Mesh size of this net is 1 inch. The nets are made of synthetic twine, rope, float, sinker, bamboo stick. The cost of building a new net is approximately 30000-50000 BDT. Almost 810 number of people are needed to operate this net. Fishers reported that a new net might last up to 1-1.5 years. Preservation process of the net is straightforward. It can be preserved by drying under the sun. Seine net is used to catch large fishes, e.g., Labeo rohita, Hypophthalmichthys molitrix, Catla catla, Notopterus chitala, Wallago attu.

\subsubsection{Choto ber jal}

This net is smaller in size compared to boro ber jal. Choto ber jal also has a wings and rope. These nets are equipped with upper and lower bamboo lines. The upper portion of the net is attached with floats. Various synthetic twines are used to construct this net such as nylon although mosquito nets are more famous due to cheaper and easily available. Mesh size of the net varies according to the size of the species caught. Almost 6-8 peoples are engaged in fishing operation while using this net. One part of the choto ber jal is spread in the water in a semi-circular way while other part exist till the bank of the water body. Someone carries the rest of the net is spread in the water in a semi-circular way. Both ends of the nets are closed together by two parties of fishermen. The construction cost of this net is 20000-25000, and the net lasts for 8-10 months. Preservation process of the net is not difficult. It can be preserved by drying under the sun. Several species e.g., Cirrhinus cirrhosus, Labeo rohita, Catla catla, Labeo kalbasu, Macrobrachium rosenbergii are caught by the choto ber jal.

\subsubsection{Lift net}

The local name of lift net is dharma jal/khara jal. The net looks like triangular-shaped, two bamboo poles are fixed at an angle about 35 degrees. Two bamboo poles are $4-5 \mathrm{~m}$ in length, and the anterior portion of the net is 1-2 m. A strong twine is a bind at the anterior of the net. Some bamboo sticks are bound with the twine for the mouth of net to be opened. Lift net is mostly operated by hand and foot. A variety of synthetic twines are used for net making. Moreover, nylon ropes are mostly used to construct this type of nets. Mesh size of these nets is about 0.1-0.2 inch. No fish attracting device is used in this net. The making cost of the lift net is about 10000$12000 \mathrm{taka} / \mathrm{net}$, and the net lasts for 1-5 years. The net frame is tied with the bamboo stage which is placed over the water surface, and the triangular portion with mesh is lowered to water surface where fish easily enter and are trapped. After pulling up the net from the water body, trapped fishes are collected. This net catches Smallsized fishes. No chemical or medicine is used for the preservation process except sun drying. This net catches Corica soborna, Alopius vulpinus, Anabas testudineus, Brachypleura movazeelandiae.

\subsubsection{Push Net}

Push nets are triangular bamboo made frame with mesh having a long handle. Fishermen can easily operate this net by pushing its long handle. The longer portion of the bamboo pole works as the handle. These nets are let down in the water for capturing fish. Various synthetic twines such as nylon, polyamide monofilaments, polypropylene, polyvinyl chloride are used for constructing the push net (FAO, 1986). Mesh size is about 0.10.2 inch. The construction cost includes 4000-4500taka/net. It lasts for 1-2 years. Preservation process of the net is very simple. It can be preserved by drying under the sun. This net mainly catches Corica soborna, Alopius 
vulpinus, Anabas testudineus, Brachypleura movazeelandiae, Pseudapocryptes elongates, Macrobrachium rossenbergii.

\subsubsection{Gill net}

Gill nets are arranged with such a mesh size that the desired fish can be caught by fastening gill. Fishermen often use a series of gill net altogether or a single gill net for capturing fish. Gill net is very common fishing gear. Gill net can be used in both the deep and shallow waters. Current jal is a kind of gill net locally available in the study area.

\subsubsection{Current jal}

Current jal is rectangular in shaped. It is monofilamentous and has little mesh size $(25-50 \mathrm{~mm})$. Synthetic twines are used for this net, such as monofilament, nylon, etc. This net is set in a place for catching fish while setting the several net numbers of pieces are joined together. Mesh size of current jal may vary based on the size of the species to be captured. Current jal with larger mesh sizes is about $(30-50 \mathrm{~mm})$ and with smaller mesh sizes is about $(10-20 \mathrm{~mm})$. The construction cost of $1000 \mathrm{~m}$ long current jal ranges from BDT 600 to 900. This is, however, for one-time use. It can be preserved by drying the net using sunlight and put it in dry place. This net mainly catches Labeo rohita, Heteropneustes fossilis, Catla catla, Mystus aor, Channa punctatus, Wallago attu, Anabas testudineus.

\subsubsection{Fishing trap}

Fishing traps are sedentary nets or pots designed in such a way where fish can enter voluntarily but cannot escape. Such traps are either baited or non-baited. Different materials are used for making traps such as wood, split bamboo, netting wires etc. Anta is a type of fishing trap, available in the study area.

\subsubsection{Anta or vashon or charu}

Anta is made of thin and narrow bamboo splits that are attached together with coconut thread. Typically, the length is greater than the height and width. It has two mouths or fish passes; one in the front side another one on the behind. At the upper side, there is a small opening to collect trapped fishes. Each door extends from the base to the apex. Used mainly for trapping small fishes, shrimps etc. the gear may be baited or not.

\subsection{Fishing crafts}

\subsubsection{Dingi nauka}

Dingi nauka is $5-8 \mathrm{~m}$ in length, $1-2 \mathrm{~m}$ in breadth. The bost is constructed by bamboo, woods (usually rain tree, mehogani, shill koroi), iron, tin etc. the smaller boats are cast-off deck, but the larger one is equipped with a deck made of half bamboo splits, betel nut trees, palm tree etc. Hood is absent in small boats, but bigger boats usually possess wooden handle and planks blade. Sail if present it is rectangular, made of cloths and is supported by bamboo poles attached diagonally. 5-6 persons are needed to operate this boat. Carrying capacity is a $300-400 \mathrm{~kg} / 5-6 \mathrm{~m}$ boat. The construction cost of this boat is $30000-50000 \mathrm{tk} / 5-6 \mathrm{~m}$ boat. The boat is needed to repair after 5-6 months, and the repairing cost is $30000-40000$ taka/5-6m boat. The boat lasts for $2-3$ years. Dingi nauka is a mechanized or non-mechanized boat, and it is propelled by engines/sail. After 5-6 months the boat needs to colour with tar or pitch and repair when damage occurs. The boat is used for operating beshal jal, purse net.

\subsubsection{Kosha nauka}

Kosha boats generally possess flat bottom without any well-defined mats. Two sides of the boats are joined together posteriorly and anteriorly, forming pointed joint ends. The ends of the boats are not much raised from the water level. The length and the breadth of the boats vary from $3.5-8 \mathrm{~m}$ and $1-1.8 \mathrm{~m}$ respectively and depth from $0.5-1 \mathrm{~m}$. The boat does not possess hood, but it is provided with a deck made up of bamboo splits or wooden planks or both. Oars are made of bamboo with wooden plank blades. The boat is constructed by bamboo, wood (usually rain tree, mehogani, shil koroi), iron, tin etc. 3-4 persons are needed to operate this boat. Carrying capacity of this boat is about $160-170 \mathrm{~kg} / 8 \mathrm{~m}$ boat. The construction cost of this boat is about $15000-$ $20000 / 4-8 \mathrm{~m}$ boat. The boat is needed to repair after 5-6 months, and the repairing cost is $2000-3000 \mathrm{tk} / 4-8 \mathrm{~m}$ boat. The boat lasts for 2-2.5 years. Kosha nauka is a non-mechanized boat, and it is propelled by 2-3 fishermen either by rowing or sailing. After 5-6 months the boats need to colour with tar or pitch and repair when the damage occurs. The boat is used for operating jhaki jal/cast net. 


\subsubsection{Chandi nauka}

Chandi nauka is slightly prolonged in both ends. Stern of this boat is much higher than the bow. The anterior and posterior part of the boat possesses plank deck, while the central region is provided with detachable split bamboo decking. Hood is situated in the central part of the boat and made of bamboo mating and reeds. Sail if present is rectangular or square in outline and is placed in front of the hood. A topsail is occasionally used for rapid movement. Four to six pairs are required to manipulate the boat. The oars are made of long bamboo poles with blades made of planks. The boat is propelled either by oars and sailor by 6 or $12 \mathrm{hp}$ engine. The boat is constructed by bamboo, wood (sundori, jarul, garjan), iron, tin etc. the durability of the boats varies from 5-6 years depending upon the timber used. 5-8 persons are required to operate this boat. The name of the boat comes after the net it operates, i.e. chandi jal. Length of this boat varies from $6-15 \mathrm{~m}$. Carrying capacity of the boat is a $2000-2500 \mathrm{~kg} / 15 \mathrm{~m}$ boat. The boat is needed to repair after 5-6 months. The construction cost of this boat is a 50000-100000taka/6-15m boat. After 5-6 months the boat needs to colour with tar or pitch and repair when damage occurs. Traditionally chandi jal is used other net can also be used depends on fishermen's choice.

\subsubsection{Soto tempu}

This boat is also locally known as a trawler. It has a rounded bottom; the anterior and posterior part of the boat is high above the water level. The back part is not as pointed as the front side: the length, width, and height of the boat $6-8 \mathrm{~m}, 1-1.5 \mathrm{~m}$, and $2-3 \mathrm{~m}$. The boat is constructed by bamboo, wood (usually gamari, chaplas), iron, tin etc. The bottom of the hull is made by digging out or hollow out single tree trunk. The sides are made of fitting plants. The stern is $1-1.5 \mathrm{~m}$ higher than the bow. The deck and hood of the boat are made of wooden planks while the oars have plank paddle fitted to a long bamboo handle. The hood is in the posterior half of the boat. 46 persons need to operate this boat. Carrying capacity of the boat is a $4000-45000 \mathrm{~kg} / 6-8 \mathrm{~m}$ boat, and the boat is needed to repair after 5-6 months. The construction cost of the boat is an $8000-10000$ taka/6-8m boat. Soto tempu lasts for 3-4 years. Soto tempu is a mechanized boat and is propelled by engines. After 5-6 months the boat needs to colour with burn oil and repair when damage occurs. This boat is generally used for operating gill nets.

\section{Conclusions}

Our study exhibits the availability, use, detail description, way of operation of different kinds of fishing gears and crafts in Gumti river, Muradnagar by survey method. The study was carried out by the collection of primary data through surveying individual fishermen. The present study was based on field survey where primary data was collected from the fishermen. The major advantages of survey method include less expensive, and its coverage is much broader. Although fishers are experienced with a subsistence economy, they are still operating local traditional fishing net, gears and crafts. No modern instruments such as compass, freezing capacity are used on the boats. Most of the fishermen are financially needy, and they don't get any governmental help. They have to loan money from the landlord to make their fishing nets and crafts and bound to maintain the landlord's rules. Fishermen often do not get the actual price of fish because of the local representatives.

Consequently, the poor fishermen remain poor as they have to pay back a loan. So the governmental help is badly needed to the fishermen. Our study could fill the existing gap of knowledge about the resources and give information about the sustainable use of these physical resources (mainly nets and crafts) at Muradnagar.

\section{Acknowledgements}

We thank local fish farmers for their kind cooperation to fulfill our study objectives.

\section{Conflict of interest}

None to declare.

\section{References}

Ahmed N, 1954. Fishery Craft of East Pakistan, East Pakistan Government Press, Dhaka, 9 pp.

Bangladesh Centre of Advanced Studies, 1989. Final Report, ENIMOF Project, Development of Fisheries, Ministry of Fisheries and Livestock, Government of Bangladesh.

Banglapedia, 2012. National Encyclopedia of Bangladesh, Asiatic Society of Bangladesh.

Chakraborty SC, MA Hossain and ME Haq, 1995. Traditional inland fishing methods in Bangladesh. J. Asiat. Soc. Bangladesh Sci., 21: 19-27.

Chong K, 1979. An economic appraisal of the fisheries in the Chanpur, Muhuri, Halda and Ichamati project areas, Irrigation Fisheries Development project working document No. 13, DOF, 19 pp. 
Dewan S and MA Mazid, 1994. Productivity, Exploitation and Fishing Technology of Inland Open-water Fisheries, Bangladesh, A Report prepared for the project "Assistance to Fisheries Research Institute", 1-35 pp.

DOF, 2005. Compendium on Fish Fortnight, Matshya BHaban, Department of Fisheries, Dhaka, 48 pp.

FAO, 1986. "Hydrobiology of Kaptai Reservoir", Aquatic Research Group (ARG), FAO/UNDP Final Report No. DP/BGD/79, University of Chittagong, Bangladesh.

ISO, 1974. International Organization of Standardization. Available: https://www.iso.org/home.html.

Jhingram VG, 1963. Report on the fisheries of Chilka Lake, Bull center Int. Fish, Inst., 1: 113 pp.

Karim M, 1978. Status and Potential of Bangladesh Fisheries, Ministry of Fisheries and Livestock, government of Peoples Republic of Bangladesh, $125 \mathrm{pp}$.

Khaleque MA and MR Islam, 1985. The relative use and efficacy of common commercial and subsistence fishing gears in Bangladesh. Bangladesh J. Aquac., 6-7: 35-38.

Kibria G, 1983. The composition of jag fishery (brush shelter) of the Dhakatia River, Bangladesh. Bangladesh J. Zool., 11: 127-132.

Moula G, Y Mahmud, MGM Alam and MA Hossain, 1993. Fiahing crafts and gears of Meghna River. Progress. Agric., 4: 59-65.

Rahman S, B Chakraborty and C Tesai, 1993. The Fishing gear selectivity study, Preliminary progress report (May, 1993), Fisheries Research Institute, Santahar, Bagura, 1-27 pp.

Uddin MK, MR Hasan, SK Paul and T Sultana, 2020. Socio-economic condition and livelihood status of the fisherman community at Muradnagar upazila in Cumilla. Fish. Aquac. J., 11: 279.

Wahiduzzaman M and MR Hasan, 2020. Fishing gear and craft used at Nijhum Dwip under Hatiya Upazila of Noakhali District, Bangladesh. World J. Fish Mar. Sci., 12: 1-5. 